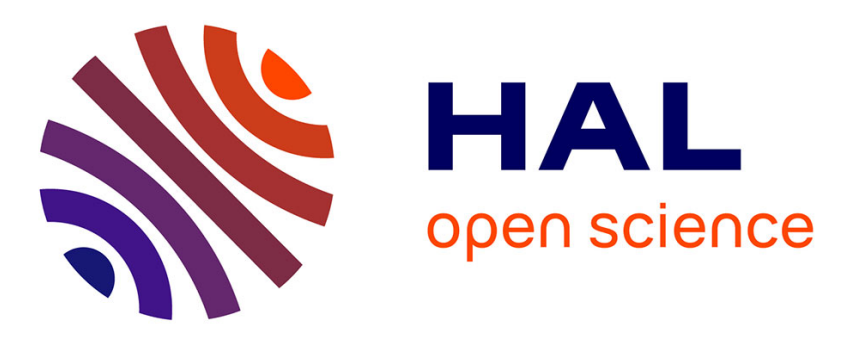

\title{
Genotype diversity of group A rotavirus strains in children with acute diarrhea in urban Burkina Faso, 2008-2010.
}

\author{
Isidore J O Bonkoungou, Susan Damanka, Idrissa Sanou, Fidèle \\ Tiendrébéogo, Sheick O Coulibaly, Fabienne F. Bon, Kaisa Haukka, Alfred S \\ Traoré, Nicolas Barro, George E Armah
}

\section{To cite this version:}

Isidore J O Bonkoungou, Susan Damanka, Idrissa Sanou, Fidèle Tiendrébéogo, Sheick O Coulibaly, et al.. Genotype diversity of group A rotavirus strains in children with acute diarrhea in urban Burkina Faso, 2008-2010.. Journal of Medical Virology, 2011, 83 (8), pp.1485-90. 10.1002/jmv.22137 . hal00602806

\section{HAL Id: hal-00602806 https://hal.science/hal-00602806}

Submitted on 23 Jun 2011

HAL is a multi-disciplinary open access archive for the deposit and dissemination of scientific research documents, whether they are published or not. The documents may come from teaching and research institutions in France or abroad, or from public or private research centers.
L'archive ouverte pluridisciplinaire HAL, est destinée au dépôt et à la diffusion de documents scientifiques de niveau recherche, publiés ou non, émanant des établissements d'enseignement et de recherche français ou étrangers, des laboratoires publics ou privés. 


\title{
Genotype Diversity of Group A Rotavirus Strains in Children With Acute Diarrhea in Urban Burkina Faso, 2008-2010
}

\author{
Isidore J.O. Bonkoungou, ${ }^{1,2 *}$ Susan Damanka, ${ }^{3}$ Idrissa Sanou, ${ }^{4,5}$ Fidèle Tiendrébéogo, ${ }^{1}$ \\ Sheick O. Coulibaly, ${ }^{2,5}$ Fabienne Bon, ${ }^{6}$ Kaisa Haukka, ${ }^{7}$ Alfred S. Traoré, ${ }^{1}$ Nicolas Barro, ${ }^{1}$ and \\ George E. Armah ${ }^{3}$ \\ ${ }^{1}$ Laboratoire de Biologie Moléculaire, d'Epidémiologie et Surveillance des Bactéries et Virus transmis par les \\ Aliments, CRSBAN / UFR-SVT, Université de Ouagadougou, Burkina Faso \\ ${ }^{2}$ Laboratoire National de Santé Publique, Ouagadougou, Burkina Faso \\ ${ }^{3}$ Noguchi Memorial Institute for Medical Research, University of Ghana, Accra, Ghana \\ ${ }^{4}$ Laboratoire de Bactériologie et Virologie du CHU-Yalgado Ouédraogo, Ouagadougou, Burkina Faso \\ ${ }^{5}$ UFR-Sciences de la Santé, Université de Ouagadougou, Burkina Faso \\ ${ }^{6}$ Laboratoire Interactions Muqueuses-Agents Transmissibles-UFR Médecine, Dijon, France \\ ${ }^{7}$ Department of Infectious Disease Surveillance and Control, National Institute for Health and Welfare, Helsinki, Finland
}

In this study, the diversity of $G$ and $P$ genotypes of rotavirus strains in Burkinabe children were examined. Between November 2008 and February 2010, 447 stool samples were collected from children $<5$ years of age with acute diarrhea visiting hospital in Ouagadougou. Group A rotavirus was previously detected in $151 / 447(33.8 \%)$ of the samples tested by an immunochromatographic test and these samples were now tested further for rotavirus G and $\mathrm{P}$ genotypes by RT-PCR. Of these, the rotavirus type genes were amplified by RT-PCR for $140 / 151(92.7 \%)$ samples and $G$ and $P$ genotypes were successfully determined for 81 $(57.9 \%)$ and $130(92.9 \%)$ samples, respectively. The most prevalent $\mathrm{G}$ genotypes were $\mathrm{G} 1,34 /$ $140(24.3 \%)$, and G9, $21 / 140(15 \%)$, while the predominant $P$ genotypes were $P[6], 56 / 140$ $(40 \%)$, and $P[8], 54 / 140(38.6 \%)$. Among the single infections, $63 / 140(45 \%)$, the predominant G/P combinations were: G1P[8] (33\%), G9P[8] $(29 \%)$, and G2P[6] (14\%). The unusual strains G1P[9] (3\%), G12P[6] (3\%), G10P[6] (2\%), and G2P[8] (2\%) were also detected. In a high number of strains $61 / 140(43.6 \%)$, the G genotype could not be determined and mixed infections were determined in $17 / 140(12.1 \%)$ of strains identified. This study highlights the high diversity and presence of unusual rotavirus strains in children in Burkina Faso. J. Med. Virol. 83:1485-1490, 2011. (๑) 2011 Wiley-Liss, Inc.

KEY WORDS: rotavirus; children; genotypes; RT-PCR; gastroenteritis; Burkina Faso

\section{INTRODUCTION}

Rotavirus is a major cause of acute gastroenteritis in infants and young children worldwide [Desselberger et al., 2006]. The World Health Organization (WHO) estimates that globally 527,000 deaths occur each year among children as a result of rotavirus infection [WHO, 2007]. Although the incidence of infection among children in developed and developing countries is similar, outcomes vary widely with about $82 \%$ of fatalities occurring in less developed regions [Parashar et al., 2003, 2006]. Furthermore, rotavirus infections are an important cause of hospitalization in young children, causing considerable social and economic burden in low-income countries [Hoshino and Kapikian, 2000; Parashar et al., 2003].

Group A human rotaviruses are non-enveloped $70 \mathrm{~nm}$ RNA viruses belonging to the Reoviridae family and exhibit considerable genetic diversity. Rotaviruses have a three capsid layer structure [Estes, 2001] with the outer capsid made up of a

Grant sponsor: Laboratoire de Biologie Moléculaire, d'Epidémiologie et de Surveillance des Bactéries et Virus transmis par les aliments, CRSBAN/UFR-SVT (University of Ouagadougou); Grant sponsor: National Public Health Laboratory (LNSP) in Burkina Faso; Grant sponsor: WHO Regional Rotavirus Reference Laboratory, Department of Electron Microscopy and Histopathology, Noguchi Memorial Institute for Medical Research (NMIMR) of the University of Ghana.

*Correspondence to: Isidore J.O. Bonkoungou, Laboratoire National de Santé Publique, 09 BP 24 Ouagadougou, Burkina Faso. E-mail: ouindgueta@gmail.com

Accepted 19 April 2011

DOI 10.1002/jmv.22137

Published online in Wiley Online Library

(wileyonlinelibrary.com). 
protease sensitive protein designated as VP4 and a glycoprotein designated as VP7. The nature of two outer capsid proteins of the virus, VP4 and VP7, elicits the production of neutralizing antibodies to the virus [Hoshino et al., 1985; Offit et al., 1986] and allows to define the $\mathrm{P}$ (for $\mathrm{P}$ sensitive) and $\mathrm{G}$ (for glycoprotein) serotypes of the virus. Currently, $23 \mathrm{G}$ genotypes and $32 \mathrm{P}$ genotypes have been described, based on nucleotide sequence variation [Matthijnssens et al., 2008a,b, 2009; Ursu et al., 2009; Collins et al., 2010]. Global epidemiologic surveys have identified G1P[8], G2P[4], G3P[8], G4P[8], and G9P[8] as the most common global G/P genotype combinations associated with diarrhea in humans [Glass et al., 2006; Estes and Kapikian, 2007]. However, recent studies in developing countries have shown increased identification of a high proportion of rotavirus strains with unusual G/P combinations, which may have implications for vaccine efficacy [Gentsch et al., 2005; Santos and Hoshino, 2005; Todd et al., 2010]. Several studies conducted in Ghana, Ivory Coast and Nigeria, close neighbors of Burkina Faso, have reported the high incidence of unusual G/P genotype combinations with the emergence of G9 strains as important cause of gastroenteritis [Armah et al., 2003, 2010a; Akran et al., 2010; Aminu et al., 2010]. Currently, two rotavirus vaccines [Rotarix (GSK Biologicals, Rixensart, Belgium) and RotaTeq (Merck \& Co. Inc., West Point, PA)] have been licensed and implemented in immunization programs for children in many countries in Americas and Europe [Ruiz-Palacios et al., 2006; Vesikari et al., 2006]. Results from recently efficacy trials of these vaccines in Africa-Ghana, Mali, Kenya [Armah et al., 2010b], and in South Africa and Malawi [Madhi et al., 2010]-have shown good efficacy of these vaccines and protection in infants. Results from these studies have culminated in the recommendation by the WHO for the introduction of rotavirus vaccines for all infants and inclusion of these vaccines in the extended program of immunization (EPI) of countries [WHO, 2009]. The WHO further recommends the putting in place surveillance programs to help in the monitoring of rotavirus strains and the determination of vaccine effectiveness.

Although a number of studies have been published on rotavirus genotypes circulating in West Africa, little is known about the situation in Burkina Faso. To date, only one report on rotavirus genotypes isolated 10 years ago in Burkina Faso has been published [Steele et al., 2010], which reported the predominance of the unusual rotavirus strain G2P[6].

The present work is a continuation of a previous study on rotavirus epidemiology in Burkina Faso, in which group A rotavirus prevalence was found to be $33.8 \%$ [Bonkoungou et al., 2010]. The objective of this study was to determine the diversity of $\mathrm{G}$ and $P$ genotypes of the rotavirus strains circulating among children with acute diarrhea in Burkina Faso during two consecutive rotavirus seasons from 2008 to 2010.

\section{MATERIALS AND METHODS}

\section{Rotavirus Positive Samples}

Rotavirus positive samples used for the present study were those in which group A rotavirus was detected in a previous study, for which full details of the sampling and testing procedures as well as clinical and sociodemographic information of the children are published [Bonkoungou et al., 2010]. Briefly, 447 children under the age of 5 years, who had diarrhea and/or were admitted to the Centre Médical avec Antenne Chirugicale (CMA) du Secteur 30 of Ouagadougou between November 2008 and February 2010 were enrolled in the study. Of the 447 stool samples tested by immunochromatographic (SD Bioline Rota/ Adeno $^{\mathbb{R}}$; Standard Diagnostics, Inc., Kyonggi-Do, South Korea), 150 (33.8\%) revealed the presence of group A rotavirus. These rotavirus-positive samples were submitted for $\mathrm{G}$ and $\mathrm{P}$ genotyping conducted at the WHO Regional Rotavirus laboratory (RRL) at the Department of Electron Microscopy and Histopathology, Noguchi Memorial Institute for Medical Research of the University of Ghana.

\section{RNA Extraction and Reverse Transcription}

Rotaviral RNA was extracted from $500 \mu$ l of $10 \%$ faecal suspensions in PBS and purified with the RNaid Kit (BIO 101, La Jolla, CA) [Gentsch et al., 1992]. The extracted RNA was used for a semi-nested multiplex RT-PCR after specific priming with VP7 and VP4 consensus primer pairs [Gouvea et al., 1990; Gentsch et al., 1992]. Briefly, $1 \mu$ l of the specific primer pair (Beg9/End9) for VP7 or (Con3/Con2) for VP4 was added to $8 \mu \mathrm{l}$ of the extracted RNA, heated at $94^{\circ} \mathrm{C}$ for $5 \mathrm{~min}$ to denature the RNA and immediately chilled on ice for $2 \mathrm{~min}$. This was followed by the addition of $3.2 \mu \mathrm{l}$ of the reverse transcriptionase (RT) reaction mix (62.5 $\mu \mathrm{M}$ of each dNTP, Promega; and $5 \mathrm{U}$ of AMV reverse transcriptase; Promega Corporation, Madison, WI). The RT was carried out by incubation at $42^{\circ} \mathrm{C}$ for $30 \mathrm{~min}$. This was followed by a 30 cycles of PCR ( $1 \mathrm{~min}$ denaturing at $94^{\circ} \mathrm{C}, 2 \mathrm{~min}$ annealing at $42^{\circ} \mathrm{C}$, and $3 \mathrm{~min}$ extending at $72^{\circ} \mathrm{C}$ ) followed by a final extension cycle at $72^{\circ} \mathrm{C}$ for $7 \mathrm{~min}$. The reaction mixture contained 1.5 U Taq polymerase (Gibco BRL, Life Technologies, Gaitherburg, MD).

\section{G and $P$ Typing PCR}

G typing was performed by using a seminested PCR method as described by Gouvea et al. [1990] and adapted by Iturriza-Gomara et al. [2004] and Banerjee et al. [2007]. Briefly, in the first round, the fulllength VP7 gene was obtained with primer pair Beg9/ End9. This was followed by a second-round multiplex PCR, which incorporated primer End9, the G-typespecific primer RVG9, and primers aBT1, aCT2, aET3, aDT4, aAT8, aFT9, G10, and G12, which are specific for $\mathrm{G}$ types $1,2,3,4,8,9,10$, and 12 , respectively. For $\mathrm{P}$ typing, a similar method using a 
seminested PCR adapted from the method described by Gentsch et al. [1992] was used. In the first-round PCR, the full-length VP8* gene products were obtained using the consensus primers Con2 and Con3. This was then followed by a second-round typing PCR which incorporated primer Con3 and primers 1T-1, 2T-1, 3T-1, 4T-1, and 5T-1, which are specific for types $\mathrm{P}[8], \mathrm{P}[4], \mathrm{P}[6], \mathrm{P}[9]$, and $\mathrm{P}[10]$, respectively. All PCR products were examined by gel electrophoresis in $1.2 \%$ agarose gels containing $4 \mu \mathrm{g}$ of ethidium bromide/ml and the $\mathrm{G}$ and $\mathrm{P}$ types were determined by the molecular weights of the amplicons.

\section{RESULTS}

\section{Genotyping Results}

Of the 151 group A rotavirus positive samples, 140 $(92.7 \%)$ had sufficient sample material for further characterization by RT-PCR. Of these, seven (5\%) could not be assigned either a $\mathrm{G}$ and $\mathrm{P}$ type specificity (non-typeable samples). The G genotype was successfully determined for $79(56.4 \%)$ and $\mathrm{P}$ genotype for $130(92.9 \%)$ rotavirus samples (Table I).

\section{Frequencies of $\mathbf{G}$ and $\mathbf{P}$ Genotypes}

Considering $\mathrm{G}$ and $\mathrm{P}$ types separately in the 140 positive samples characterized by RT-PCR, the most common G types determined were G1 (24.3\%), G9 (15\%), and G2 (8.6\%). Other genotypes determined were G4 (2.1\%), G3 (0.7\%) and the newly emerging genotypes G12 (1.4\%), G10 (0.7\%). Similarly, the commonest $\mathrm{P}$ types detected were $\mathrm{P}[6](40 \%)$ and $\mathrm{P}[8]$ $(38.6 \%)$. Other P types detected were P[4] (3.6\%) and the unusual VP4 type P[9] (1.4\%) (Table I).

\section{Distribution of G/P Combinations}

Both $\mathrm{G}$ and $\mathrm{P}$ type specificities could be assigned successfully to $63(45 \%)$ of the samples characterized (Fig. 1). The common infecting rotavirus strains detected during the period of study in children with acute diarrhea in Burkina Faso were G1P[8] (33\%), G9P[8] (28\%), and G2P[6] (14\%). Less common types detected were: G1P[6] (5\%), G4P[8] and G9P[6] (3\% each), G4P[6] and G2P[4] (2\% each). In addition, in this study, unusual rotavirus strains bearing the genotypes G1P[9], G12P[6], G10P[6], and G2P[8] were detected as shown in Figure 1. Thirteen of the strains characterized had mixed $\mathrm{P}$ genotypes and five were of mixed G genotypes. Only one sample exhibited both mixed G and P genotypes (Table I). In $54(38.6 \%)$ samples, the $\mathrm{P}$ genotype could be determined but the $\mathrm{G}$ type could not be determined. Likewise in three (2.1\%) samples, the $\mathrm{G}$ type could be determined but the $\mathrm{P}$ type was not and in seven (5\%) both the $\mathrm{G}$ and $\mathrm{P}$ types could not be determined.

\section{Seasonal Distribution of Rotavirus Genotypes}

During the study period, rotavirus G/P genotype combinations (single types) were detected during December to March, corresponding to the dry season and relatively cool and cold nights. The most common prevailing strain changed over the 2-year study period. During the first rotavirus season, the most common rotavirus genotypes detected were G1P[8] and G2P[6] whilst during the second season the most common genotype was G9P[8], (Fig. 2).

\section{DISCUSSION}

This study reports on the detection and characterization of rotavirus strains in Ouagadougou during 2008-2010, representing the longest-term study for rotavirus surveillance in Burkina Faso. The present work is a continuation of a previous study on rotavirus epidemiology in Burkina Faso [Bonkoungou et al., 2010], which revealed that rotavirus accounted for $33.8 \%$ of diarrheal episodes. Genotyping of human rotavirus strains revealed a great diversity of $G$ and $P$ genotypes circulating in urban Burkina Faso. Previous rotavirus studies indicated that G1P [8], G2P [4], G3P [8], G4P [8], and G9P [8] represent $74 \%$ of

TABLE I. Distribution of Rotavirus G and P Genotypes Among Children $<5$ Years of Age in Burkina Faso, November 2008-February 2010

\begin{tabular}{lcccccccccc}
\hline & \multicolumn{10}{c}{ G type } \\
\cline { 2 - 11 } P type & G1 & G2 & G3 & G4 & G9 & G10 & G12 & Mixed $^{\text {a }}$ & NTG & All \\
\hline P4 & 0 & $1(0.7)$ & 0 & 0 & 0 & 0 & 0 & 0 & $4(2.9)$ & $5(3.6)$ \\
P6 & $3(2.1)$ & $9(6.4)$ & 0 & $1(0.7)$ & $2(1.4)$ & $1(0.7)$ & $2(1.4)$ & $1(0.7)$ & $37(26.4)$ & $56(40)$ \\
P8 & $21(15)$ & $1(0.7)$ & 0 & $2(1.4)$ & $18(12.9)$ & 0 & 0 & $3(2.1)$ & $9(6.4)$ & $54(38.6)$ \\
P9 & $2(1.4)$ & 0 & 0 & 0 & 0 & 0 & 0 & 0 & 0 & $2(1.4)$ \\
Mixed & $5(3.6)$ & $1(0.7)$ & $1(0.7)$ & 0 & $1(0.7)$ & 0 & 0 & $1(0.7)$ & $4(2.6)$ & $13(9.3)$ \\
NTP & $3(2.1)$ & 0 & 0 & 0 & 0 & 0 & 0 & 0 & $7(5.0)$ & $10(7.1)$ \\
All & $34(24.3)$ & $12(8.6)$ & $1(0.7)$ & $3(2.1)$ & $21(15)$ & $1(0.7)$ & $2(1.4)$ & $5(3.6)$ & $61(43.6)$ & $140(100)$ \\
\hline
\end{tabular}

NTG, non-typeable for G; NTP, non-typeable for P.

Data are number $(\%)$ of strains $(\mathrm{n}=140)$.

aThe mixed G type found in this study were (0.7\%) for each, G1G9[P8], G1G10[P4], G1G10[P8], and G1G10[P6].

b The mixed $\mathrm{P}$ type found in this study were G1[P6]P[8](3.6\%), P[6]P[8](1.4\%) and (0.7\%) for each [P8]P[10], P[4][P6]P[8], P[4][P8]P[9], G1[P4]P[8], G1P[4][P8]P[9], G1P[4][P6]P[8], G2P[6][P8]P[9], and G3[P6]P[8].

${ }^{\mathrm{c}} \mathrm{G}$-mixed-P-mixed type found in this study was G1G2 P[6][P8](0.7\%). 


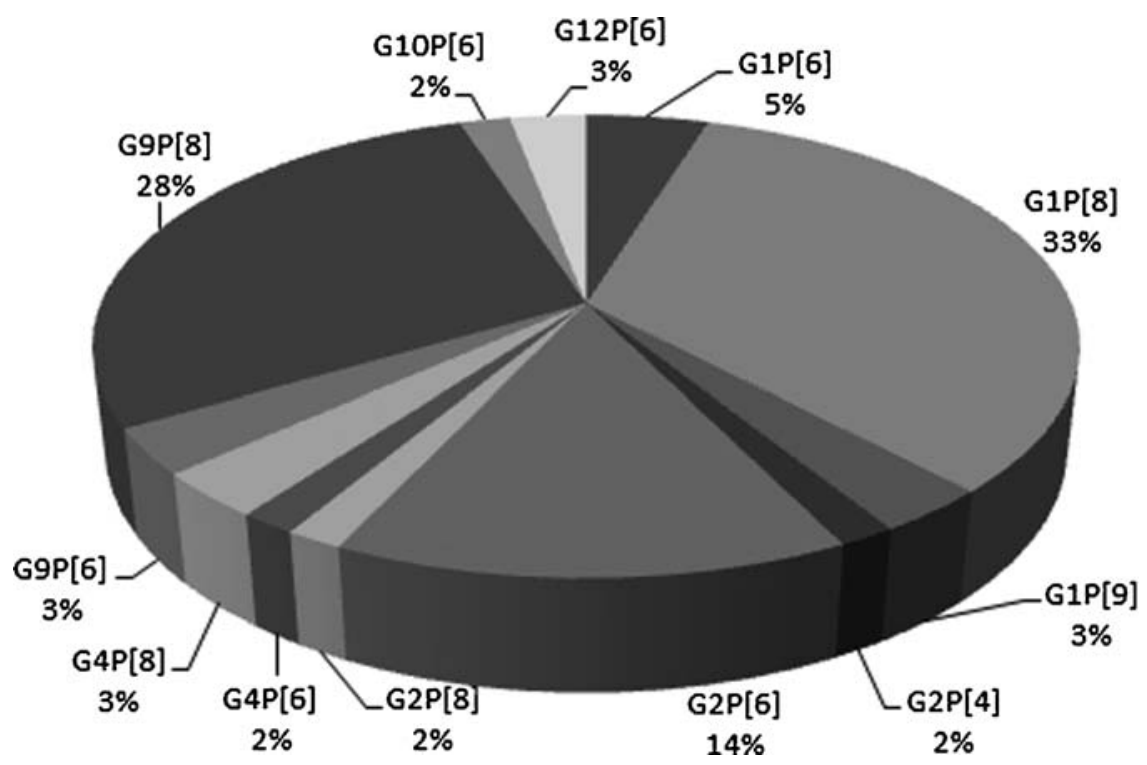

Fig. 1. Frequencies (\%) of rotavirus G/P combinations among 63 samples for which both $\mathrm{G}$ and $\mathrm{P}$ were determined between November 2008 and February 2010.

globally identified strains [Gentsch et al., 2005]. However, these strains are less prevalent comprising of only $37 \%$ of those strains in Africa [Todd et al., 2010]. In the current survey, these five most common genotypes globally constituted $64 \%$ of detected rotavirus strains in Ouagadougou. G1 strains were the most commonly detected $(24.3 \%)$ in the 140 positive samples, frequently in combination with $\mathrm{P}[8]$. The second $\mathrm{G}$ specificity found most frequently in this study was G9 (15\%), which emerged as the fifth most important human genotype. G9 was detected mostly in combination with $\mathrm{P}[8]$, as has been reported elsewhere in the West African sub-region [Armah et al., 2003, 2010c].

The unusual G/P type G2P[6] was found to be the third most common genotype 14\% (Fig. 1) associated with diarrhea in children in Burkina Faso. Adah et al. [2001] and Salu et al. [2003] reported about a decade ago the existence of this genotypes in the region. Recently, the importance of G2P[6] in Burkina Faso has been reported [Steele et al., 2010]. Also studies in Ghana and Cote d'Ivoire, which are close neigbors to Burkina Faso, reported high prevalence of G2P[6] and the researchers suspected it to be an emerging strain in the sub-region of West Africa [Armah et al., 2001, 2010a; Akran et al., 2010]. Other unusual G/P combinations recently reported in Africa [Steele et al., 2003; Page et al., 2010] were found in low frequencies, notable combinations being G12P[6], G1P[6], and G2P[8] which represented two $(3 \%)$, one $(2 \%)$, and one $(2 \%)$, respectively, of the single $\mathrm{G} / \mathrm{P}$ combination infections (Fig. 1). These genotypes were probably secondary to reassortment among co-circulating human genotypes [Iturriza-Gómara et al., 2001; Maunula and Von Bonsdorff, 2002] and were the most common unusual

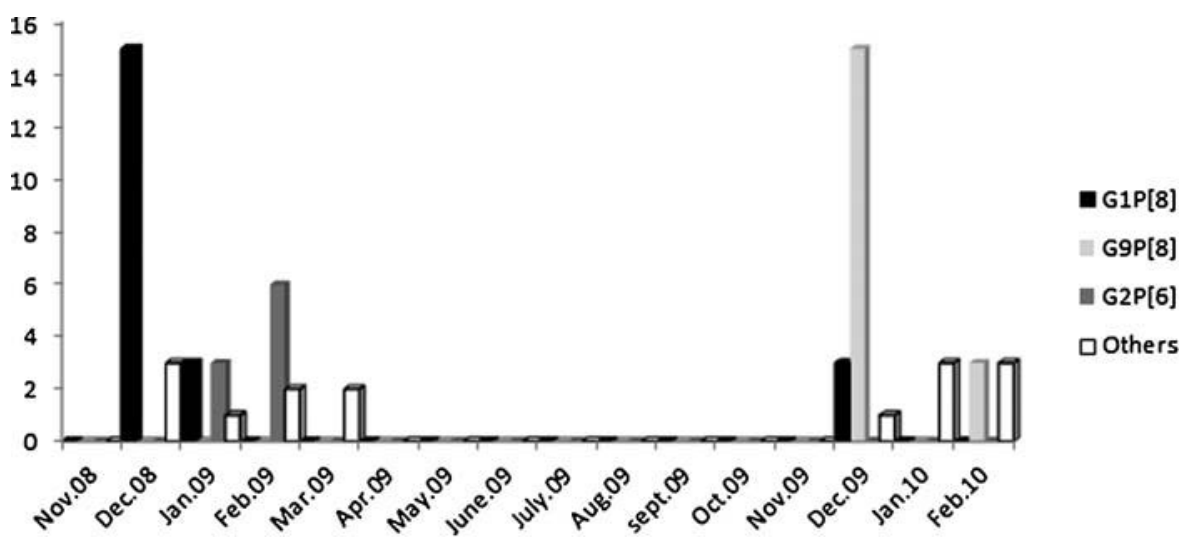

Fig. 2. Monthly distribution of rotavirus G/P combinations (single types) circulating in Ouagadougou, Burkina Faso, November 2008-February 2010. Others: G1P[6], G1[P9], G2[P4], G2[P8], G4[P6], G4P[8], G9[P6],G10[P6], G12[P6]. 
strains found in West Africa also previously [Armah et al., 2010c]. The presence of G9 strains and unusual isolates in Burkina Faso and its neighboring countries may be due to the continuous population movement between these countries.

Mixed infections have already been reported representing about $12.4 \%$ of isolated rotavirus strains in Africa [Todd et al., 2010], as was also the case in the present study $(12.1 \%)$. This study also documents the detection of rotavirus strains normally associated with animals (cattle and a cat); two G1P[9], one G10P[6], and three G10 mixed infections. G10 and $P[9]$ have been recovered sporadically from humans in various geographical areas. In developing countries, the lack of adequate sanitation and potable water supplies and the close association of humans with domestic and farm animals could give rise to reassortment between human and animal strains with the potential of cross-species infections [Cook et al., 2004].

During this study, $43.6 \%$ of samples were G untypable despite several attempts. This might be due to common strains with accumulated point mutations not recognized by the primers used or new unidentified G types, and only sequence analysis of VP7 PCR products will confirm this.

Rotavirus occurs mostly during the period from December to March, corresponding to the dry season and relatively cool and cold nights, as has been reported in Burkina Faso and elsewhere in West Africa [Binka et al., 2003; Rodrigues et al., 2007; Akran et al., 2010; Bonkoungou et al., 2010]. During the study period, rotavirus strains varied from one season to another: the most common strains G2P[6] and G9P[8] were identified during the first rotavirus season and G1P[8] during both rotavirus seasons (Fig. 2). Several studies have shown that large fluctuations in the genotype distribution of human rotaviruses occur continuously from 1 year to another or from one place to another [Tcheremenskaia et al., 2007; Yang et al., 2008].

In conclusion, this study, in addition to describing the rotavirus $\mathrm{G}$ and $\mathrm{P}$ genotypes circulating in human infections in Burkina Faso, highlights the existence of significant diversity of rotavirus strains with unusual $\mathrm{G}$ and $\mathrm{P}$ combinations. These data will be useful for making an informed decision about the introduction of rotavirus vaccine in Burkina Faso and provides baseline data for future vaccine studies.

\section{ACKNOWLEDGMENTS}

We thank the staff of the Electron Microscopy and Histopathology Department of NMIMR for their technical assistance.

\section{REFERENCES}

Adah MI, Wade A, Taniguchi K. 2001. Molecular epidemiology of rotavirus in Nigeria: Detection of unusual strains with G2P[6] and G8P[1] specificities. J Clin Microbiol 39:3969-3975.
Akran V, Peenze I, Akoua-Koffi C, Kette H, De Beer MC, Dosso M Steele AD. 2010. Molecular characterization and genotyping of human rotavirus strains in Abidjan, Cote d'Ivoire. J Infect Dis 202:220-224.

Aminu M, Page NA, Ahmad AA, Umoh JU, Dewar J, Steele AD 2010. Diversity of rotavirus VP7 and VP4 genotypes in Northwestern Nigeria. J Infect Dis 202:198-204.

Armah GE, Pager CT, Asmah RH, Anto FR, Oduro AR, Binka F, Steele D. 2001. Prevalence of unusual human rotavirus strains in Ghanaian children. J Med Virol 63:67-71.

Armah GE, Steele AD, Binka FN, Esona MD, Asmah RH, Anto F, Brown D, Green J, Cutts F, Hall A. 2003. Changing patterns of rotavirus genotypes in Ghana: Emergence of human rotavirus G9 as a major cause of diarrhoea in children. J Clin Microbiol 41:2317-2322.

Armah GE, Hoshino Y, Santos N, Binka F, Damanka S, Adjei R, Honma S, Tatsumi M, Manful T, Anto F. 2010a. The global spread of rotavirus G10 strains: Detection in Ghanaian children hospitalized with diarrhea. J Infect Dis 202:231-238.

Armah GE, Sow SO, Breiman RF, Dallas MJ, Tapia MD, Feikin DR, Binka FN, Steele AD, Laserson KF, Ansah NA, Levine MM, Lewis K, Coia ML, Attah-Poku M, Ojwando J, Rivers SB, Victor JC, Nyambane G, Hodgson A, Schodel F, Ciarlet M, Neuzil KM. 2010b. Efficacy of pentavalent rotavirus vaccine against severe rotavirus gastroenteritis in infants in developing countries in sub-Saharan Africa: A randomised, double-blind, placebo-controlled trial. Lancet 376:606-614.

Armah GE, Steele AD, Esona MD, Akran VA, Nimzing L, Pennap G. 2010c. Diversity of rotavirus strains circulating in West Africa from 1996 to 2000. J Infect Dis 202:64-71.

Banerjee I, Ramani S, Primrose B, Iturriza-Gomara M, Gray JJ, Brown DW, Kang G. 2007. Modification of rotavirus multiplex RT-PCR for the detection of G12 strains based on characterization of emerging G12 rotavirus strains from South India. J Med Virol 79:1413-1421.

Binka FN, Anto FK, Oduro AR, Awini EA, Nazzar AK, Armah GE Asmah RH, Hall AJ, Cutts F, Alexander N, Brown D, Green J, Gray J, Iturriza-Gómara M, Navrongo Rotavirus Research Group. 2003. Incidence and risk factors of paediatric rotavirus diarrhoea in Northern Ghana. Trop Med Int Health 8:840-846.

Bonkoungou IJ, Sanou I, Bon F, Benon B, Coulibaly SO, Haukka K, Traoré AS, Barro N. 2010. Epidemiology of rotavirus infection among young children with acute diarrhoea in Burkina Faso. BMC Pediatr 10:94.

Collins PJ, Martella V, Sleator RD, Fanning S, O'Shea H. 2010. Detection and characterization of group A rotavirus in asymptomatic piglets in southern Ireland. Arch Virol 153:1247-1259.

Cook N, Bridger J, Kendall K, Iturriza Gomora M, El-Attar L, Gray J. 2004. The Zoonotic potential of rotavirus. J infect 48:289-302.

Desselberger U, Wolleswinkel-van den Bosch J, Mrukowicz J, Rodrigo C, Giaquinto C, Vesikari T. 2006. Rotavirus types in Europe and their significance for 638 vaccinations. Pediatr Infect Dis J 25:30-41.

Estes MK. 2001. Rotaviruses and their replication. In: Knipe DM, Howley PM, editors. Fields virology. 4th edition. Philadelphia, PA: Lippincott Williams \& Wilkins, pp 1747-1785.

Estes M, Kapikian A. 2007. Rotaviruses. In: Fields BN, Knipe DM, Howley PM, Griffin DE, Lamb RA, Martin MA, Roizman B, Straus ES, editors. Fields virology. 5th edition. Philadelphia, PA Lippincott Williams \& Wilkins, pp 1917-1974.

Gentsch JR, Glass RI, Woods P, Gouvea V, Gorziglia M, Flores J, Das BK, Bhan MK. 1992. Identification of group A rotavirus gene 4 types by polymerase chain reaction. J Clin Microbiol 30:1365-1373.

Gentsch JR, Laird AR, Bielfelt B, Griffin DD, Banyai K, Ramachandran M, Jain V, Cunliffe NA, Nakagomi O, Kirkwood CD Fischer TK, Parashar UD, Bresee JS, Jiang B, Glass RI. 2005. Serotype diversity and reassortment between human and animal rotavirus strains: Implications for rotavirus vaccine programs. J Infect Dis 192:S146-S159.

Glass RI, Parashar UD, Bresee JS, Turcios R, Fischer TK, Widdowson MA, Jiang B, Gentsch JR. 2006. Rotavirus vaccines: Current prospects and future challenges. Lancet 368:323-332.

Gouvea V, Glass RI, Woods P, Taniguchi K, Clark HF, Forrester B, Fang ZY. 1990. Polymerase chain reaction amplification and typing of rotavirus nucleic acid from stool specimens. J Clin Microbiol 28:276-282. 
Hoshino Y, Kapikian A. 2000. Rotavirus serotypes: Classification and importance in rotavirus epidemiology, immunity and vaccine development. J Health Popul Nutr 18:5-14.

Hoshino Y, Sereno M, Midthun K, Flores J, Kapikian AZ, Chanock RM. 1985. Independent segregation of two antigenic specificities (VP3 and VP7) involved in neutralization of rotavirus infectivity. Proc Natl Acad Sci USA 82:8701-8704.

Iturriza-Gomara M, Isherwood B, Desselberger U, Gray J. 2004. Characterization of $\mathrm{G} 10 \mathrm{P}[11]$ rotaviruses causing acute gastroenteritis in neonates and infants in Vellore. Ind J Clin Microbiol 42:2541-2547.

Iturriza-Gómara M, Isherwood B, Desselberger U, Gray J. 2001. Reassortment in vivo: Driving force for diversity of human rotavirus strains isolated in the United Kingdom between 1995 and 1999. J Virol 75:3696-3705.

Madhi SA, Cunliffe NA, Steele D, Witte D, Kirsten M, Louw C Ngwira B, Victor JC, Gillard PH, Cheuvart BB, Han HH, Neuzil KM. 2010. Effect of human rotavirus vaccine on severe diarrhea in African infants. N Engl J Med 362:289-298.

Matthijnssens J, Ciarlet M, Heiman E, Arijs I, Delbeke T, McDonald SM, Palombo EA, Iturriza-Gómara M, Maes P, Patton JT, Rahman M, Van Ranst M. 2008a. Full genome-based classification of rotaviruses reveals a common origin between human Wa-like and porcine rotavirus strains and human DS-1-like and bovine rotavirus strains. J Virol 82:3204-3219.

Matthijnssens J, Ciarlet M, Rahman M, Attoui H, Banyai K, Estes MK, Gentsch JR, Iturriza-Gómara M, Kirkwood C, Martella V, Mertens PPC, Nakagomi O, Patton JT, Ruggeri FM, Saif LJ, Santos N, Steyer A, Taniguchi K, Desselberger U, Van Ranst M. $2008 \mathrm{~b}$. Recommendations for the classification of group A rotaviruses using all 11 genomic RNA segments. Arch Virol 153:16211629 .

Matthijnssens J, Bilcke J, Ciarlet M, Martella V, Banyai K, Rahman M, Zeller M, Beutels P, Van Damme P, Van Ranst P. 2009. Rotavirus disease and vaccination: Impact on genotype diversity. Future Microbiol 4:1303-1316.

Maunula L, Von Bonsdorff CH. 2002. Frequent reassortments may explain the genetic heterogeneity of rotaviruses: Analysis of Finnish rotavirus strains. J Virol 76:11793-11800.

Offit PA, Shaw RD, Greenberg HB. 1986. Passive protection against rotavirus-induced diarrhea by monoclonal antibodies to surface proteins VP3 and VP7. J Virol 58:700-703.

Page N, Esona M, Seheri M, Nyangao J, Bos P, Mwenda J, Steele D. 2010. Characterization of genotype G8 strains from Malawi, Kenya, and South Africa. J Med Virol 82:2073-2081.

Parashar UD, Hummelman EG, Bresee JS, Miller MA, Glass RI. 2003. Global illness and deaths caused by rotavirus disease in children. Emerg Infect Dis 9:565-572.

Parashar UD, Gibson CJ, Bresse JS, Glass RI. 2006. Rotavirus and severe childhood diarrhea. Emerg Infect Dis 12:304-306.

Rodrigues A, de Carvalho M, Monteiro S, Mikkelson SC, Aaby P, Molbakk K, Fischer TK. 2007. Hospital surveillance of rotavirus infection and nosocomial transmission of rotavirus disease among children in Guinea-Bissau. Pediatr Infect Dis J 26:233237 .
Ruiz-Palacios GM, Pérez-Schael I, Velázquez FR, Abate H, Breuer T, Clemens SC, Cheuvart B, Espinoza F, Gillard P, Innis BL, Cervantes Y, Linhares AC, López P, Macías-Parra M, OrtegaBarría E, Richardson V, Rivera-Medina DM, Rivera L, Salinas B, Pavía-Ruz N, Salmerón J, Rüttimann R, Tinoco JC, Rubio P, Nuñez E, Guerrero L, Yarzábal JP, Damaso S, Tornieporth N, Sáez-Llorens X, Vergara RF, Vesikari T, Bouckenooghe A, Clemens R, De Vos B, O'Ryan M, for the Human Rotavirus Vaccine Study Group. 2006. Safety and efficacy of an attenuated vaccine against severe rotavirus gastroenteritis. N Engl J Med 354:11-22

Salu OB, Audu R, Geyer A, Steele AD, Oyefolu AOB. 2003. Molecular epidemiology of rotaviruses in Nigeria: Detection of unusual strains G2P[6] and G8P[1] specificities. J Clin Microbiol 41:913914.

Santos N, Hoshino Y. 2005. Global distribution of rotavirus serotypes/genotypes and its implication for the development and implementation of an effective rotavirus vaccine. Rev Med Virol 15:29-56.

Steele AD, Peenze I, de Beer MC, Pager CT, Yeats J, Potgieter N, Ramsaroop U, Page NA, Mitchell JO, Geyer A, Bos P, Alexander JJ. 2003. Anticipating rotavirus vaccines: Epidemiology and surveillance of rotavirus in South Africa. Vaccine 21:354 360 .

Steele AD, Page N, de Beer M, Sawadogo S. 2010. Antigenic and molecular characterization of unusual rotavirus strains in Burkina Faso in 1999. J Infect Dis 202:S225-S230.

Tcheremenskaia O, Marucci G, De Petris S, Ruggeri FM, Dovecar D, Sternak SL, Matyasova I, Dhimolea MK, Mladenova Z, Fiore L, the Rotavirus Study Group. 2007. Molecular epidemiology of rotavirus in central and southeastern Europe. J Gin Micro biol 45:2197-2204.

Todd S, Page NA, Steele DS, Peenze I, Cunliffe NA. 2010. Rotavirus strain types circulating in Africa: Review of studies published during 1997-2006. J Infect Dis 202:S34-S42.

Ursu K, Kisfali P, Rigo D, Ivanics E, Erdelyi K, Dan A, Melegh B, Martella V, Bányai K. 2009. Molecular analysis of the VP7 gene of pheasant rotaviruses identifies a new genotype, designated G23. Arch Virol 154:1365-1369.

Vesikari T, Matson DO, Dennehy P, Van Damme P, Santosham M, Rodriguez Z, Dallas MJ, Heyse JF, Goveia MG Black SB, Shinefield HR, Christie CD, Ylitalo S, Itzler RF, Coia ML, Onorato MT, Adeyi BA, Marshall GS, Gothefors L, Campens D, Karvonen A, Watt JP, O’Brien KL, DiNubile MJ, Clark HF, Boslego JW, Offit PA, Heaton PM, Rotavirus Efficacy Safety Trial (REST) Study Team. 2006. Safety and efficacy of pentavalent human-bovine (WC3) reassortant rotavirus vaccine in preventing rotavirus gastroenteritis and reducing associated health care resource utilization. N Engl J Med 354:23-33.

WHO. 2007. Rotavirus vaccines. Wkly Epidemiol Rec 82:285-296.

WHO. 2009. Rotavirus vaccination. Wkly Epidemiol Rec 84:213-236.

Yang XL, Matthijnssens J, Sun H, Muhamaiti J, Zhang B, Nahar S, Van Ranst M, Rahman M. 2008. Temporal changes of rotavirus strain distribution in a city in the northwest of China, 19962005. Int J Infect Dis 12:11-17. 